\title{
Correlation between anthropometric parameters and cardiometabolic risk in military Correlación entre parámetros antropométricos y riesgo cadiometabólico en militares
}

Marly Melo Zanetti, Leandro de Lima e Silva, Marcio Antonio de Barros Sena, Eduardo Borba Neves, Paula Fernandez Ferreira, Felipe Keese, Rodolfo Alkmim Moreira Nunes, Marcos de Sá Rego Fortes BrazilianArmy Research Institute of Physical Fitness (Brazil)

\begin{abstract}
Introduction: The objective was to verify the relationship between anthropometric parameters and biomarkers associated with cardiometabolic diseases in military personnel. Methods: This is an analytical cross-sectional study, which involved 26 male Brazilian Army (EB) soldiers, with a mean age of $32.7 \pm 2.12$, physically active and from various EB military organizations. Serological clinical biomarkers were evaluated: glucose (GLUC), insulin (INSUL), triglyceride (TRIG), total cholesterol (TC) and high-density lipoprotein (HDL-c) and anthropometric variables obtained with a dual energy X-ray absorption densitometer (DXA) and body circumferences. The Shapiro-Wilk test and the Pearson correlation test were applied using the software Statistics ${ }^{\circledR}$ version 12.0. Results: Significant negative correlations between GLUC and lean mass $(\mathrm{LM})(\mathrm{r}=-0.46 ; \mathrm{p}=0.031)$ and fat-free mass $(\mathrm{FFM})(\mathrm{r}=-0.46 ; \mathrm{p}=0.032)$ and positive with the percentage of fat $(\% \mathrm{~F})(\mathrm{r}=0.43 ; \mathrm{p}=0.043)$. Insulin (INSUL) showed positive correlations with fat mass $(\mathrm{FM})(\mathrm{r}=0.52 ; \mathrm{p}=0.012)$; visceral adipose tissue $($ VAT $)(r=0.48 ; p=0.024)$, waist circumference $(W C)(r=0.53 ; p=0.01)$ and body mass index $(B M I)(r=0,54 ; p=0.009)$. The index of the model for assessing insulin homeostasis (HOMA-IR) showed positive correlations with $\% \mathrm{~F}(\mathrm{r}=0.44 ; \mathrm{p}=0.04), \mathrm{FM}(\mathrm{r}=0.55 ; \mathrm{p}=$ $0.007)$, VAT $(r=0.52 ; \mathrm{p}=0.014), \mathrm{WC}(\mathrm{r}=0.54 ; \mathrm{p}=0.01)$ and with the BMI $(\mathrm{r}=0.52 ; \mathrm{p}=0.014)$. Conclusion: There was a positive association between variables representing insulin resistance and those related to body fat. In addition to negative correlations between GLUC and variables related to muscle mass.
\end{abstract}

Keywords: Fat, cardiometabolic disease, biochemistry

Resumen. Introducción. El objetivo fue verificar la relación entre parámetros antropométricos y biomarcadores asociados a enfermedades cardiometabólicas en personal militar. Métodos: Se trata de un estudio analítico de corte transversal, que involucró a 26 hombres soldados del Ejército Brasileño (EB), con una edad media de 32,7 \pm 2,12 años, físicamente activos y de diversas organizaciones militares de la EB. Se evaluaron biomarcadores clínicos serológicos: glucosa (GLIC), insulina (INSUL), triglicéridos (TRIG), colesterol total (CT) y lipoproteínas de alta densidad (HDL-c) y variables antropométricas obtenidas con densitómetro de absorción de rayos X de energía dual (DXA) y circunferencias corporales. La prueba de Shapiro-Wilk y la prueba de correlación de Pearson se aplicaron utilizando el software Statistics ${ }^{\circledR}$ versión 12.0. Resultados: Correlaciones negativas significativas entre GLIC y masa magra $(\mathrm{LM})(\mathrm{r}=-0.46 ; \mathrm{p}=0.031)$ y masa libre de grasa $(\mathrm{FFM})(\mathrm{r}=\mathrm{-}$ $0.46 ; \mathrm{p}=0.032)$ y positiva con el porcentaje de grasa $(\% \mathrm{~F})(\mathrm{r}=0,43 ; \mathrm{p}=0,043)$. La insulina (INSUL) mostró correlaciones positivas con la masa grasa $(\mathrm{MG})(\mathrm{r}=0,52 ; \mathrm{p}=0,012)$; tejido adiposo visceral $(\mathrm{IVA})(\mathrm{r}=0,48 ; \mathrm{p}=0,024)$, circunferencia de cintura $(\mathrm{CC})(\mathrm{r}=0,53 ; \mathrm{p}$ $=0,01)$ e índice de masa corporal $(\mathrm{IMC})(\mathrm{r}=0,54 ; \mathrm{p}=0,009)$. El índice del modelo para evaluar la homeostasis de la insulina (HOMA-IR) mostró correlaciones positivas con $\% \mathrm{~F}(\mathrm{r}=0.44 ; \mathrm{p}=0.04), \mathrm{MG}(\mathrm{r}=0.55 ; \mathrm{p}=0.007), \mathrm{TAV}(\mathrm{r}=0.52 ; \mathrm{p}=0.014), \mathrm{CC}(\mathrm{r}=0,54 ; \mathrm{p}=0,01)$ y con el IMC $(r=0,52 ; p=0,014)$. Conclusión: Hubo una asociación positiva entre las variables que representan la resistencia a la insulina y las relacionadas con la grasa corporal. Además de correlaciones negativas entre GLIC y variables relacionadas con la masa muscular.

Palabras clave: Grasa, enfermedad cardiometabólica, bioquímica.

\section{Introduction}

Sedentary lifestyle and physical inactivity are highly prevalent worldwide, both being related to chronic noncommunicable diseases (NCDs) and premature death. It is worth mentioning the growing interest in sedentary behavior, which encompasses daily activities related to low energy demand (Amorim \& Faria, 2012). This interest points to a relationship between this lifestyle and the increased prevalence of obesity, diabetes mellitus type 2 (DM2), and cardiovascular disease, making it a major public health problem.

Fecha recepción: 08-10-21. Fecha de aceptación: 04-02-22 Eduardo Borba Neves neveseb@gmail.com
For years, metabolic risk has been among the main factors that cause most deaths and disabilities in Brazilians, accompanied by high blood pressure and body mass index (BMI). It should be noted that, since 2005, there has been an increase in diseases linked to obesity, as the number of obese inhabitants has also increased in Brazil (Simão et al., 2013).

The location of adipose tissue plays different roles in our body, its two largest deposits are subcutaneous (retroperitoneal) and visceral (intra-abdominal) fat. These different compartments predict differentiated risks, as well as present substantial divergences related to anatomical aspects, adipocyte morphology, endocrine function, lipolytic activity, vascularization, and innervation. The venous drainage of the subcutaneous adipose tissue (TAS) is performed by the systemic 
circulation, while the visceral adipose tissue (VAT) is irrigated by the portal circulation (Oliveira et al., 2013; Schleinitz, Böttcher, Blüher, \& Kovacs, 2014).

Among the most used direct techniques in research involving the assessment of total or compartmentalized body composition are dual-energy X-ray absorption densitometry (DXA) and bioimpedance. In clinical practice, for diagnostic or monitoring purposes, densitometry, bioimpedance, and anthropometric measurements stand out (Imboden, Swartz, Finch, Harber, \& Kaminsky, 2017).

Regarding blood biomarkers, the lipid profile stands out as of great relevance in cases of obesity, being an assessment capable of determining the concentration of glucose (GLUC), insulin (INSUL), triglyceride (TRIG), total cholesterol (TC), and its fractions, such as LDL-c (Low-Density Lipoprotein), HDL-c (High-Density Lipoprotein) and VLDL-c (Very Low-Density Lipoprotein) (Carrasco, Galgani, \& Reyes, 2013; Jung \& Choi, 2014; Nelson \& Cox, 2018). Another biomarker widely used in this scenario is the insulin homeostasis assessment index (HOMAR-IR), its use concomitant with the assessment of body composition, allows us to understand the appearance in the body of risk factors associated with the development of cardiovascular diseases. It should be noted that hepatic INSUL resistance is associated with impaired gluconeogenesis suppression, resulting in hyperglycemia (Carrasco et al., 2013; Goldie et al., 2016; Jung \& Choi, 2014; Nelson \& Cox, 2018; Tam et al., 2012).

All over the world, the military is characterized by occupying the most inhospitable places in their respective countries to guarantee the sovereignty of the state where the civilian population does not carry out this occupation spontaneously. In addition, in many regions of military employment there is no availability of continuous laboratory tests to monitor the cardiometabolic risk of this population, in this sense, the use of anthropometric parameters could be a solution for monitoring this variable, combined with training well-planned physical and military-oriented (Rosa, Martinez, Marson, Fortes, \& Fernandes, 2018).

Military personnel are employed at any time in situations of operational readiness, therefore, they need to have the good physical health to be successful in the tasks performed. Therefore, the present study aimed to verify the correlation between anthropometric parameters and blood biomarkers associated with cardiometabolic diseases in Brazilian Army soldiers.

\section{Methods}

\section{Sample}

This is an analytical cross-sectional study(Thomas, Nelson, \& Silverman, 2012), which involved 26 male Brazilian Army (EB) soldiers, with a mean age of 32.7 \pm 2.12 , physically active and from various EB military organizations. The inclusion criteria were: being physically active and exercising aerobic activity of moderate intensity at least three times a week, totaling at least $12 \mathrm{~km}$ of running per week, in addition to signing the Informed Consent Form demonstrating to be a volunteer. As exclusion criteria, the following were stipulated: the subject has some pathology that makes it impossible to perform aerobic exercises, has performed strenuous exercises on the eve of data collection, and missed one of the analyzes performed or failed to fully comply with the proposed protocol.

\section{Procedures}

This study was approved by the Ethics Council of the Army's Physical Training Research Center (CAAE: 16739119.4.0000.9433). All procedures followed the criteria of the legislation in force in the country (Resolução, 2012).

The VAT measurement was performed using CoreScan VAT, a software that assesses the GV (mass in $\mathrm{g}$ and volume in $\mathrm{cm}^{3}$ ) in the android region. Detecting the thickness of the TAS layer on the sides of the android region allows the software to map the entire tissue compartment. The amount of VAT was derived by the software by subtracting the subcutaneous fat mass (24).

The percentage of fat $(\% \mathrm{~F})$, fat mass (FM), fat-free mass (FFM), and lean mass (LM) were measured with the Dual Energy Radiological Absorption (DXA) device from Lunar General Electric Healthcare, employing the software in Core 2015 version 12.20. All analyzes were performed by the same radiology technologist trained by the legal representative of the manufacturer of this equipment. To perform this exam, the individual was recommended to wear light clothing (military physical training uniform) and without metallic ornaments. For whole-body scanning, participants were placed in the supine position and instructed to remain still throughout the entire scan, starting from the top of the head to the feet. The duration of the exam to assess the whole body and the regions of interest was an average of 15 minutes and its protocol requires a 6hour fast. 
To calculate the BMI, the total body mass $(\mathrm{Kg})$ was evaluated with the aid of a calibrated and validated EKS ${ }^{\circledR}$ brand digital scale, with an accuracy of $0.05 \mathrm{~kg}$, with the participant standing, barefoot, and wearing only swimming trunks. bath; and height $(\mathrm{m})$ with a fixed stadiometer branded Sanny ${ }^{\circledR}$, Personal Caprice, with $1 \mathrm{~mm}$ precision. The military should be barefoot, without socks, with the heels in contact with the apparatus and maintaining an upright position, with the head being adjusted according to the Frankfurt plan. The measurement took place in respiratory apnea upon expiration of the individual, with the cursor at a $90^{\circ}$ angle.

To measure the waist circumference (WC) was considered the average distance between the last rib and the iliac crest, with the measurement being performed at the end of expiration, in apnea, in body parts not covered by clothing, with the subject in an upright position, with arms relaxed at the sides of the body and weight evenly distributed on both legs. The instrument used for this was an inelastic anthropometric measuring tape measuring two meters in length and precision of $1 \mathrm{~mm}$, from the Cescorf ${ }^{\circledR}$ brand. In all assessments, professionals followed the procedures and recommendations recommended by World Health Organization et al. Physical status: The use of and interpretation of anthropometry, Report of a WHO Expert Committee (Organization, 1995).

After the pre-analytical procedures, the automated liquid chemistry analyzer BT3000 (Wiener Lab, Rosario, Argentina) was used to determine the following serological clinical biomarkers: GLUC, TRIG, TC, and HDL-c, all these analyzes followed the recommendations of the specific commercial kit (Wiener Lab, Rosario, Argentina) and occurred at $37^{\circ} \mathrm{C}$. For the analysis of the INSUL concentration, the Immulite XP automation equipment (Siemens, Gwynedd, UK) was used. The method chosen for the investigation of IR was the homeostasis assessment model (HOMA) and its calculation was performed using the following formula: [fasting glucose $(\mathrm{mg} / \mathrm{dL}) \mathrm{x}$ fasting insulinemia $(\mathrm{mcU} /$ $\mathrm{mL})$ ] / 405, stipulating the HOMA-IR.

The soldiers who were part of the sample were evaluated in a single day, at the pre-defined date and time. In addition, they presented themselves in ideal conditions, according to previous guidance, such as adequate fasting, military uniform, not performing intense exercise on the previous day, as well as not drinking alcohol in the $48 \mathrm{~h}$ prior to venous collection (HENRY).

\section{Statistical analysis}

Data were treated by the program Statistics version 12.0 and presented as mean and standard deviation. Data normality was verified using the Shapiro-Wilk test and the Pearson correlation test was used to verify the association of the study variables. $\mathrm{p} d » 0.05$ was adopted as the level of significance.

\section{Results}

Descriptive data of the sample are showed in Table 1.

Table 1

Descriptive data of the 26 male Brazilian Army (EB) soldiers

\begin{tabular}{|c|c|c|c|c|}
\hline & Mean & SD & Min & Max \\
\hline AGE (years) & 32,7 & 2,1 & 30,0 & 37,0 \\
\hline BM $(\mathrm{kg})$ & $88,0 \pm$ & $\pm 10,2$ & 70,6 & 108,8 \\
\hline BMI (kg/m2) & 27,7 & 2,7 & 23,2 & 33,7 \\
\hline $\mathrm{TC}(\mathrm{mg} / \mathrm{dl})$ & $184,6=$ & $\pm 49,7$ & 5,5 & 258 \\
\hline $\operatorname{GLUC}(\mathrm{mg} / \mathrm{dl})$ & 93,3 & 6,2 & 79,0 & 106,0 \\
\hline TRIG (mg/dl) & 125,3 & 57,7 & 54,0 & 341,0 \\
\hline $\operatorname{HDL}-\mathrm{c}(\mathrm{mg} / \mathrm{dl})$ & 41,4 & 10,3 & 24,0 & 63,0 \\
\hline Insul $(\mu \mathrm{UI} / \mathrm{mL})$ & 8,9 & 4,3 & 3,0 & 21,5 \\
\hline Homa IR index & 2,0 & 0,998 & 0,72 & 4,87 \\
\hline$\% \mathrm{~F}$ & 28,1 & 5,2 & 15,0 & 36,9 \\
\hline FM $(g)$ & 25110,2 & 5601,6 & 14737,0 & 35428,0 \\
\hline $\mathrm{LM}(\mathrm{g})$ & 60931,6 & 8323,8 & 47706,0 & 79358,0 \\
\hline FFM (g) & 64226,7 & 8651,7 & 50458,0 & 83336,0 \\
\hline $\operatorname{VAT}(\mathrm{g})$ & 1052,8 & 422,7 & 392,0 & 2062,0 \\
\hline $\mathrm{WC}(\mathrm{cm})$ & 96,1 & 6,5 & 83,8 & 109,30 \\
\hline
\end{tabular}

Negative and significant correlations were found between GLUC and LM and FFM; and positive correlation with \%F. INSUL showed significant positive correlations with FM,VAT, WC and BMI.The HOMARIR showed significant positive correlations with \%F, FM, VAT, WC and BMI. The biochemical variables TRIG, HDL-c and TC did not correlate with any of the other variables as shown in Table 2 below:

Table 2.

Correlational analysis of study variables from 26 male Brazilian Army (EB) soldiers \begin{tabular}{lllllllll}
$\mathrm{N}=22$ & $\% \mathrm{~F}$ & $\mathrm{FM}(\mathrm{g})$ & LM (g) & FFM (g) & VAT (g) & WC $(\mathrm{cm})$ & $\mathrm{BM}(\mathrm{kg})$ & BMI \\
\hline
\end{tabular} $\begin{array}{lllllllll}\text { GLUC } & 0.4347 * & 0.2594 & -0.4610 * & -0.4588 * & 0.3338 & 0.1354 & -0.2559 & -0.0769\end{array}$ $(\mathrm{mg} / \mathrm{dl}) \quad \mathrm{p}=0.043 \quad \mathrm{p}=0.244 \quad \mathrm{p}=0.031 \quad \mathrm{p}=0.032 \quad \mathrm{p}=0.129 \quad \mathrm{p}=0.548 \quad \mathrm{p}=0.250 \quad \mathrm{p}=0.734$ $(\mathrm{mg} / \mathrm{dl}) \quad \mathrm{p}=0.790 \quad \mathrm{p}=0.881 \quad \mathrm{p}=0.993 \quad \mathrm{p}=0.993 \quad \mathrm{p}=0.602 \quad \mathrm{p}=0.791 \quad \mathrm{p}=0.942 \quad \mathrm{p}=0.833$ \begin{tabular}{ccccccccc}
$(\mathrm{mg} / \mathrm{dl})$ & $\mathrm{p}=0.790$ & $\mathrm{p}=0.881$ & $\mathrm{p}=0.993$ & $\mathrm{p}=0.993$ & $\mathrm{p}=0.602$ & $\mathrm{p}=0.791$ & $\mathrm{p}=0.942$ & $\mathrm{p}=0.833$ \\
\hline HDL-c & 0.1678 & -0.0147 & -0.3411 & -0.3416 & -0.1812 & -0.1224 & -0.3040 & -0.2736
\end{tabular} $(\mathrm{mg} / \mathrm{dl}) \quad \mathrm{p}=0.456 \quad \mathrm{p}=0.948 \quad \mathrm{p}=0.120 \quad \mathrm{p}=0.120 \quad \mathrm{p}=0.420 \quad \mathrm{p}=0.587 \quad \mathrm{p}=0.169 \quad \mathrm{p}=0.218$ $\begin{array}{llllllllll}\text { TC } & 0.3087 & 0.2820 & -0.1367 & -0.1334 & 0.1946 & 0,0150 & 0.0388 & -0.0605\end{array}$ \begin{tabular}{cccccccccc}
$(\mathrm{mg} / \mathrm{dl})$ & $\mathrm{p}=0.162$ & $\mathrm{p}=0.204$ & $\mathrm{p}=0.544$ & $\mathrm{p}=0.554$ & $\mathrm{p}=0.386$ & $\mathrm{p}=0.947$ & $\mathrm{p}=0.864$ & $\mathrm{p}=0.789$ \\
\hline INSUL & 0.3809 & $0.5234 *$ & 0.0997 & 0.1042 & $0.4807 *$ & $0.5345 *$ & 0.3773 & $0.5405 *$
\end{tabular} $(\mu \mathrm{UI} / \mathrm{mL}) \quad \mathrm{p}=0.080 \quad \mathrm{p}=0.012 \quad \mathrm{p}=0.659 \quad \mathrm{p}=0.644 \quad \mathrm{p}=0.024 \quad \mathrm{p}=0.010 \quad \mathrm{p}=0.083 \quad \mathrm{p}=0.009$ \begin{tabular}{llllllllll}
\hline & $0.4409 *$ & $0.5540 *$ & 0.0297 & 0.0344 & $0.5176 *$ & $0.5371 *$ & 0.3335 & $0.5151 *$
\end{tabular}

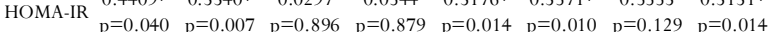
Caption: *= significant correlations $(\mathrm{p}<0.05), \% \mathrm{~F}=$ fat percentage, $\mathrm{FM}=$ fat mass, $\mathrm{LM}=$ lean mass, $\mathrm{VAT}=$ visceral adipose tissue, $\mathrm{WC}=$ waist circumference, $\mathrm{BM}=$ body mass, $\mathrm{BMI}=$ body mass index, $\quad \mathrm{GLUC}=$ glucose, $\mathrm{TRIG}=$ triglyceride, $\mathrm{HDL}-\mathrm{c}=$ high density lipoprotein, $\mathrm{TC}=$ total cholesterol, INSUL=insulin, Homa-IR=insulin homeostasi

\section{Discussion}

The aim of the present study was to verify the correlation between anthropometric parameters and blood biomarkers associated with cardiometabolic diseases in Brazilian Army soldiers. Significant 
correlations were observed between anthropometric indicators and biomarkers associated with cardiometabolic risk.

The results of the present study indicate significant negative correlations between GLUC and LM ( $\mathrm{r}=$ $0.46 ; \mathrm{p}=0.031)$ and FFM $(\mathrm{r}=-0.46 ; \mathrm{p}=0.032)$, and positive with $\% \mathrm{~F}(\mathrm{r}=0.43 ; \mathrm{p}=0.043)$. These results corroborate the study by Rosa et al. (2018) who, found in their study with EB military personnel during a peace mission, that GLUC,TC,TRIG, and HDL-c were directly proportional to fat mass, and that, in the case of that study, the military graduates (officials), who had better physical performance, showed improvement in LM, reduction in FM and biochemical markers (GLUC, HDL-c, and TRIG). Where it is noteworthy that the designs of the studies are a little different but follow the same line of reasoning, and in that study, GLUC had the same behavior with the markers related to body fat, as well as behaved inversely proportional to LM and FM in the group of the official military.

The abdominal fat mass, either visceral or subcutaneous, is involved in the pathogenesis of insulin resistance and dyslipidemia (Kumari, Kumar, \& Kant, 2019). In the present study INSUL showed positive correlations with FM ( $r=0.52 ; \mathrm{p}=0.012)$; VAT $(\mathrm{r}=$ $0.48 ; \mathrm{p}=0.024), \mathrm{WC}(\mathrm{r}=0.53 ; \mathrm{p}=0.01)$ and BMI $(\mathrm{r}$ $=0.54 ; \mathrm{p}=0.009)$. It was also observed that the index of the model for assessing insulin homeostasis (HOMAIR) showed positive correlations with $\% \mathrm{~F}(\mathrm{r}=0.44$; $\mathrm{p}$ $=0.04)$, FM $(r=0.55 ; p=0.007), \operatorname{VAT}(r=0.52 ; p=$ $0.014), \mathrm{WC}(\mathrm{r}=0.54 ; \mathrm{p}=0.01)$ and with the BMI $(\mathrm{r}=$ $0.52 ; \mathrm{p}=0.014)$. These results are in line with the study of F. Zanetti, Neufeld (2020) who used the INSUL hormone and the GLUC molecule for the validated calculation of an index that results in a numerical value which estimates the RI (HOMA-IR) to verify their associations with VAT and WC, it was observed in that study that there is a positive correlation between these variables, confirming the findings in the sample of this study of military personnel.

The lipolytic feature of VAT leads to an increase in the production of free fatty acids, which are delivered to the liver and, consequently, raise the hepatic insulin resistance (Hayashi et al., 2008). One possible reason why $\% \mathrm{~F}$ was less correlated to HOMA-IR compared to the other adiposity parameters might be by the fact that it did not only measure white adipose tissue, composed by mostly visceral adipose tissue, but also measured brown adipose, which probably is not related to insulin resistance (Castro, Kolka, Kim, \& Bergman,
2014) .

The analysis of the association between GV and other biomarkers in the same study showed the importance of body fat distribution in the metabolic profile of military personnel. It is noteworthy that the WC measure behaved as a more accurate indicator of VAT than the BMI, as it suggests a greater probability of cardiometabolic disorders (Mora, Oliver, Carmona, \& Jurado, 2021).

Still, regarding the correlations found between HOMAR-IR and the other aforementioned markers, the results corroborate the findings of F. Zanetti, Firmino Neto, Neufeld (2021) who, with the objective of researching, evaluating, and comparing body composition, through the variables VAT, LM, and FM; the IR determined by the HOMA-IR index and the variables GLU, INSUL, TRIG, TC and HDL-c in obese and non-obese Brazilian Army soldiers, observed significant differences in all variables of body composition, however, in biochemical markers. However, only INSUL and HOMAR-IR showed a significant difference.

Enriquez-Del Castillo, Hernández, Luján, and Olivares (2021) performed a cross-sectional study in which they observed that individuals with higher levels of physical activity, as the sample in this study, have lower body mass indices and amount of FM. Besides, the study by Ortega, Silventoinen, Tynelius, and Rasmussen (2012) observed an association of muscular strength with a more healthy lipid profile. Therefore, it is possible that the results of the mean values within the referential parameters observed in the variables that make up the lipid profile (TC, TRIG, and HDL-C) in the present study are due to the fact that military personnel is physically active and the study of Holt et al. (2007) corroborated these claims. Although the study by Sasai et al. (2015) developed specifically in this population did not find significant differences in relation to lipid profile variables and VAT.

In general, the prevalence of changes in body composition and blood biomarkers related to metabolic risk among civilians is higher than among military personnel from the EB. Due to the need to prepare for the main activity they perform, military personnel is more active than the general population, exercising more intensely, with greater variety and duration; this may be the explanation for the lower prevalence of risk factors responsible for the development of CNCDs and the lack of correlation of the lipid profile variables with or versus the parameters of the body composition of this study (Oliveros, Somers, Sochor, Goel, \& Lopez- 
Jimenez, 2014; Walton et al., 1995).

It can be cited as a limitation of this study the fact of the study design is cross-sectional and thus causal inferences cannot be established. Furthermore, in a future study, it is planned the raise the sample size for a better representation of the Brazilian army personnel.

\section{Conclusion}

It can be concluded that are a positive association between variables related to insulin resistance (GLUC, INSUL, and HOMA-IR) with those related to body fat composition (\%F, VAT, WC, and BMI). It is also worth mentioning the significant negative correlations between GLUC and variables related to muscle mass (LM and FFM). These results corroborate those in the literature regarding the importance of analyzing the achievement of fat distribution and the increase in LM in combating metabolic diseases.

As a practical application, our results showed the relevance of measuring $\mathrm{WC}$ as a health risk indicator in overweight individuals, as they have a higher risk of developing diabetes and/or other cardiometabolic diseases.

\section{References}

Amorim, P., \& Faria, F. J. M. (2012). Dispêndio energético das atividades humanas e sua repercussão para a saúde. 8(Supl. 2), 295-302.

Carrasco, N. F., Galgani, F. J. E., \& Reyes, J. M. J. R. M. C. L. C. (2013). Síndrome de resistencia a la insulina. Estudio y manejo. 24(5), $827-$ 837.

Castro, A. V. B., Kolka, C. M., Kim, S. P., \& Bergman, R. N. (2014). Obesity, insulin resistance and comorbidities-Mechanisms of association. Arquivos Brasileiros de Endocrinologia \& Metabologia, 58, 600 609.

Enriquez-Del Castillo, L.A., Hernández, N. C., Luján, R. C., \& Olivares, L.A.F. (2021). Capacidades físicas y su relación con la actividad física y composición corporal en adultos (Physical capacities and their relationship with physical activity and body composition in adults). Retos, 41, 674-683.

Goldie, C., Taylor,A. J., Nguyen, P., McCoy, C., Zhao, X.-Q., \& Preiss, D. J. H. (2016). Niacin therapy and the risk of new-onset diabetes: a meta-analysis of randomised controlled trials. 102(3), 198-203.

Hayashi, T., Boyko, E. J., McNeely, M. J., Leonetti, D. L., Kahn, S. E., \& Fujimoto,W.Y.(2008).Visceral adiposity, not abdominal subcutaneous fat area, is associated with an increase in future insulin resistance in JapaneseAmericans. Diabetes, 57(5), 1269-1275.

Henry, J. (2012). Diagnóstico Clínico e Tratamento-Por Métodos laboratoriais: Nelson Gomes de Oliveira Ed: Manole ltda. 18Ed. Pag.

Holt, H., Wild, S., Wareham, N., Ekelund, U., Umpleby, M., ShojaeeMoradie, F., Byrne, C. (2007). Differential effects of fatness, fitness and physical activity energy expenditure on whole-body, liver and fat insulin sensitivity. Diabetologia, 50(8), 1698-1706.

Imboden, M.T., Swartz,A. M., Finch, H.W., Harber, M. P., \& Kaminsky, L.A.J.P.O. (2017). Reference standards for lean mass measures using
GE dual energy x-ray absorptiometry in Caucasian adults. 12(4), e0176161.

Jung, U. J., \& Choi, M.-S. J. I. j. o. m. s. (2014). Obesity and its metabolic complications: the role of adipokines and the relationship between obesity, inflammation, insulin resistance, dyslipidemia and nonalcoholic fatty liver disease. 15(4), 6184-6223.

Kumari, R., Kumar, S., \& Kant, R. (2019). An update on metabolic syndrome: Metabolic risk markers and adipokines in the development of metabolic syndrome. Diabetes \& Metabolic Syndrome: Clinical Research \&Reviews, 13(4), 2409-2417.

Mora, R. M. S., Oliver,A. J. S., Carmona,W. S., \& Jurado, J.A. G. (2021). Efecto de un programa de ejercicio físico sobre la condición física y la grasa visceral en personas con obesidad (Effect of a physical exercise program on physical fitness and visceral fat in people with obesity). Retos, 39, 723-730.

Nelson, D. L., \& Cox, M. M.(2018). Princípios de Bioquímica de Lehninger-7: ArtmedEditora.

Oliveira,A. G.,Araujo,T. G., Carvalho, B. M., Guadagnini, D., Rocha, G. Z., Bagarolli, R.A., .. . Saad, M. J.J. O. (2013).Acute exercise induces a phenotypic switch in adipose tissue macrophage polarization in diet induced obese rats. 21(12), 2545-2556.

Oliveros, E., Somers, V. K., Sochor, O., Goel, K., \& Lopez-Jimenez, F. (2014).The concept of normal weight obesity. Progress in cardiovascular diseases, 56(4), 426-433.

Organization, W. H. (1995). Physical status: The use of and interpretation of anthropometry, Report of a WHO Expert Committee: World Health Organization.

Ortega, F.B., Silventoinen, K.,Tynelius, P., \& Rasmussen, F.(2012). Muscular strength in male adolescents and premature death: cohort study of one million participants. Bmj, 345, e7279.

Resolução, B. (2012). 466/2012. Diretrizes e normas regulamentadoras de pesquisas envolvendoseres humanos.

Rosa, S. E. d., Martinez, E. C., Marson, R. A., Fortes, M. d. S. R., \& Fernandes, J. (2018). Military Physical training, muscular strength, and body composition of Brazilian Military Personnel. Revista Brasileira de Medicina do Esporte, 24, 153-156.

Sasai, H., Brychta, R. J., Wood, R. P., Rothney, M. P., Zhao, X., Skarulis, M. C., \& Chen, K.Y. (2015). Does visceral fat estimated by dualenergy X-ray absorptiometry independently predict cardiometabolic risks in adults? J Diabetes SciTechnol, 9(4), 917-924.

Schleinitz, D., Böttcher, Y., Blüher, M., \& Kovacs, P. J. D. (2014). The genetics of fat distribution. 57(7), 1276-1286.

Simão,A. F., Précoma, D. B., Andrade, J. P.d., Correa Filho, H., Saraiva, J., Oliveira, G., .. . Avezum Junior, A. J. A. b. d. c. (2013). I Diretriz brasileira de prevenção cardiovascular. 101(6), 1-63.

Tam, C. S., Xie, W., Johnson, W. D., Cefalu, W.T., Redman, L. M., \& Ravussin, E. J. D. c. (2012). Defining insulin resistance from hyperinsulinemic-euglycemic clamps. 35(7), 1605-1610.

Thomas, J. R., Nelson, J. K., \& Silverman, S. J. (2012). Métodos de pesquisa em atividade física: Artmed Editora.

Walton, C., Lees, B., Crook, D., Worthington, M., Godsland, I. F., \& Stevenson, J. C. (1995). Body fat distribution, rather than overall adiposity, influences serum lipids and lipoproteins in healthy men independently of age. Am J Med, 99(5), 459-464.

Zanetti, F., Firmino Neto, Neufeld.(2021).Association between visceral fat and biomarkers in military members of the Brazilian Army. SODEBRAS, 16(182):38-43.

Zanetti,F., Neufeld.(2020).Análise comparativa da composição corporal e marcadores séricos em militares não obesos e obesos do Exército Brasileiro. Coleção Pesquisa em Educação Física, 20(1): 31-38. 